\title{
Soil Microbial Activity and Functional Diversity in Primeval Beech Forests
}

\author{
Lyudmila Symochko ${ }^{1}$, Volodymyr Patyka ${ }^{2}$, Vitaly Symochko ${ }^{1}$ and Antonina Kalinichenko ${ }^{3}$ \\ 1. Biological Faculty, SHEI “Uzhhorod National University”, Uzhhorod 88000, Ukraine \\ 2. D. K. Zabolotny Institute of Microbiology and Virology NASU, Kyiv 03680, Ukraine \\ 3. Engineering Faculty, Opole University, Opole 45040, Poland
}

\begin{abstract}
Virgin forests are unique ecosystems, which can be used as etalon for basic biocoenotic investigation. Soil microorganisms are very sensitive reagents on influence of biotical factors, and at the same time are the active producers of phytotoxic and phytostimulating exometabolites. Studies of soil microbiota were conducted in virgin beech forests of Shyrokoluzhansky massif of the Carpathian Biosphere Reserve. It was found the ratio and the number of different ecological-trophic groups of soil microorganisms changes with altitude. So the number of ammonificators with increasing of altitude above sea level was reduced. The soil at altitude of 1,100 meters above sea level was characterized by minimum content of organotrophes $-1.22 \times 10^{6}$ (CFU-colony forming units $/ 1$ g.a.d.s.). At the altitude of 500 meters content of ammonificators increased at six times and was $7.07 \times 10^{6} \mathrm{CFU} / 1$ g.a.d.s., which indicates to accumulation of the soil organic matter. Similar changes occurred with the number of bacteria which are using mineral forms of nitrogen for their nutrition. Their maximum quantity $\left(4.32 \times 10^{6} \mathrm{CFU} / 1\right.$ g.a.d.s. $)$ was in the soil of biotope disposed at altitude of 500 meters above sea level. Fluctuations in the number of soil micromycetes of virgin forest ecosystems have not been as significant as the bacterial microbiota (within $17 \times 10^{3}-28 \times 10^{3} \mathrm{CFU} / 1$ g.a.d.s.). Among a wide spectrum of bacterial microbiota were isolated strains with high phytostimulating action.
\end{abstract}

Key words: Soil microorganisms, primeval beech forests, biological activity of soil, phytotoxicity of soil, biocoenotic activity of microorganisms.

\section{Introduction}

A primeval beech forests are the biogeocoenoses which were created during phylocoenogenesis in corresponding to soil-climatic conditions and landscapes. Autotrophic and heterotrophic elements of primeval forest ecosystems and pedosphere have no indications of such antropogenic influence which could change their natural status and sylvagenesis. Hence they function as homeostasis ecosystems [1]. As etalon ecosystems, they better combine above resistance and stability with high productivity biomass. Therefore the virgin forests reliably indicate the direction of restoration of disturbed ecosystems $[2,3]$. Virgin forests are essential for the conservation of biological and genetic diversity. They reserve the

Corresponding author: Lyudmila Symochko, Ph.D., Assoc. Prof., research fields: soil science, environmental microbiology and ecology. E-mail: lyudmilassem@gmail.com. relict and endemic species of flora and fauna. The study of primeval forest is a unique opportunity to explore the natural structure, diversity and genetic structure of unmodified forest and ecosystem dynamical processes and relationships that occur in them under the influence of ecological factors. Despite of the intensive exploitation of forests in the last ten centuries, its area decreased by 3.5 times, and virgin forest ecosystems which have special value remained only in the Carpathian Mountains. Moreover, since most European forest stands have been managed for centuries [4], very little is known about the diversity, ecology, and distribution of soil microorganisms in natural, undisturbed forest ecosystems in Europe. The few remnants of natural forests which could be potentially investigated, are not larger than 50-100 ha, while continuous forest areas of more than 1,000 ha are very rare. In the Transcarpathian region of Ukraine 
(south-west), the CBR (Carpathian Biosphere Reserve) offers a unique opportunity for studying the biodiversity and natural processes of virgin or primeval forest ecosystems, i.e. forests that have never been significantly modified by human activity. The region covers an area of about 53,650 ha and became part of the World Network of Biospheres Reserves of UNESCO in 1992. However, it should be noted that the attention of researchers focused mainly on studies of flora and fauna biodiversity $[5,6]$ and almost never directed to the ecological study of soil microbial communities. Microbial communities degrade most of the organic material that settled on the forest soils. The organic matter decomposition rate depends on physical factors, substrate quality and the type of microbial community. The degradation of certain compounds by specific bacteria, leads to succession of microbial community until all the substrate is completely decomposed [7]. Some saprophytic fungi and bacteria, are the primary agents that induce decomposition by the degradation of organic compounds as: cellulose, hemicellulose, pectin and lignin [8]. Bacteria have an important role in the nutrient cycling. The distribution of bacteria in forest soils is mostly determined by vegetation and soil chemical characteristics. For example, the study conducted by E. Hackl, compared the bacterial communities of six forests under different pine and oak vegetation. The results showed that Gram-positive bacteria communities, especially actinomycetes, were more abundant under conifer forests than under oak coverage. These results suggest that bacterial communities are adaptive to the soil chemistry. Due to this fact, the purpose of the research was to determine the number of different ecological-trophic groups of soil microorganisms, biological activity and phytotoxicity of soil, intensity of microbiological processes by index of pedotrophity, oligotrophity and isolation of microbial strains with phytostimulating action.

\section{Materials and Methods}

Samples of soil for study were taken in the virgin forests of Shyrokoluzhansky massif of the Carpathian Biosphere Reserve, Ukraine. The total area of the massif is about 15,033 ha [8]. The massif consists of two contiguous areas (foresteres): Uholka and Shyrokyi Lug. It lies within the Krasnyanskyi physical-geographic area of the Middle maountain-Polonyny region and Uholka physical-geographic area of the Low mountain-Rocky region. It is located between the rivers Tereblya and Teresva. The massif is separated by the mountain range Krasna from the Mokryanka river valley and lies within the Duklyanska, Prokuletska, Rakhiv and Maramorosh tectonic zones. The Duklyanska zone covers the northeastern part of the massif and is represented by sandy and clay-sandy flysch. The southwestern part of the massif is occupied with the formations of the Prokuletska zone, which is represented by massive diverse-grained sandstones. The southern part of the massif is made up of the Maramorosh rocky zone sediments, which are represented by Cretaceous sediments, Palaeogene sandstones, gridstones, aleurolites, marlstones and argillites, and also small-grained greenish-grey flysch with some stratums of grey small-grained sandstones. The soils are very stony, mostly midloamy with good water and air penetration ability [9]. Climate conditions change from mild-warm to cold. The massif belongs to three different climatic zones with annual average temperatures ranging from 0 to $+7{ }^{\circ} \mathrm{C}$ and annual average precipitation varying between $1,000 \mathrm{~mm}$ and $1,500 \mathrm{~mm}$. The temperature in July elevates from $+17{ }^{\circ} \mathrm{C}$ to $+12{ }^{\circ} \mathrm{C}$, and in January from $-3{ }^{\circ} \mathrm{C}$ to $-10{ }^{\circ} \mathrm{C}$. The sum of active temperatures changes with the altitude from $2,300{ }^{\circ} \mathrm{C}$ to $800{ }^{\circ} \mathrm{C}$. Researches were conducted from 2008 to 2014 years. Sampling was carried out by squares method in depth of $0-25 \mathrm{~cm}$ at different altitudes from $500 \mathrm{~m}$ to 1,100 $\mathrm{m}$ (Table 1). 
Table 1 Characteristics of the soil sampling location in virgin beech forests.

\begin{tabular}{llll}
\hline No. & Vegetation & $\begin{array}{l}\text { Coordinates } \\
\text { (latitude; longitude) }\end{array}$ & Altitude above sea level, m \\
\hline 1 & Fagetum (silvaticae) & $48^{\circ} 18.671^{\prime} ; 23^{\circ} 44.388^{\prime}$ & 500 \\
2 & Fagetum (silvaticae) & $48^{\circ} 21.087^{\prime} ; 23^{\circ} 43.398^{\prime}$ & 600 \\
3 & Fagetum (silvaticae) & $48^{\circ} 18.450^{\prime} ; 23^{\circ} 43.227^{\prime}$ & 700 \\
4 & Fagetum (silvaticae) & $48^{\circ} 19.928^{\prime} ; 23^{\circ} 42.879^{\prime}$ & 800 \\
5 & Fagetum (silvaticae) & $48^{\circ} 21.562^{\prime} ; 23^{\circ} 43.425^{\prime}$ & 900 \\
6 & Fagetum (silvaticae) & $48^{\circ} 19.344^{\prime} ; 23^{\circ} 45.620^{\prime}$ & 1,000 \\
7 & Fagetum (silvaticae) & $48^{\circ} 21.810^{\prime} ; 23^{\circ} 44.532^{\prime}$ & 1,100 \\
\hline
\end{tabular}

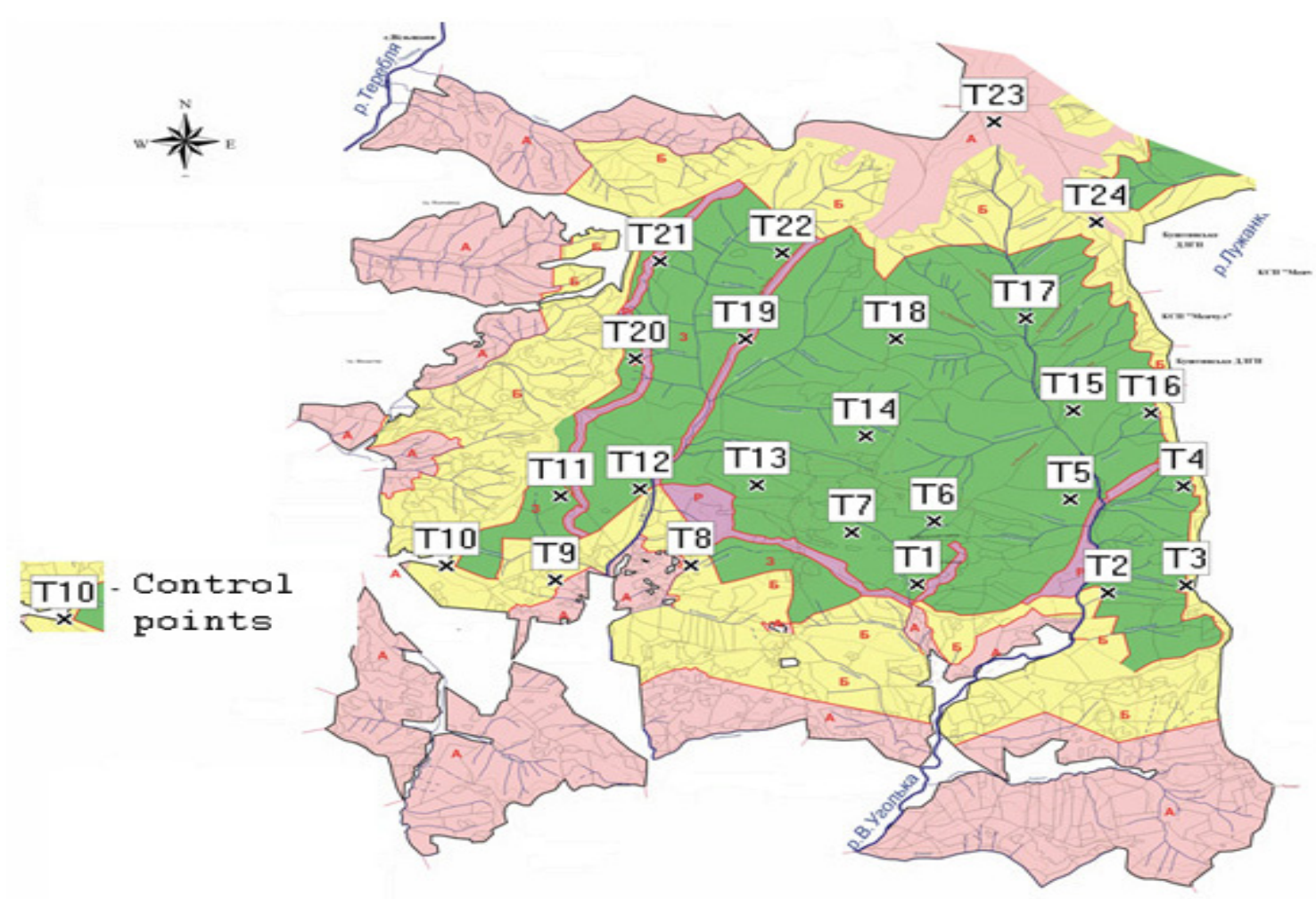

Fig. 1 Map of the soil sampling in virgin beech forests.

Microbiological analysis of soil has been carried by standard methods [9-11].

Samples of soil were collected in a sterile container from all investigated plots (Fig. 1).

The biological activity of the soil was determined by Kazeev et al. [12], direction of microbiological processes in the soil by $\mathrm{K}$. Andreyuk and methods described by Volkohon [13, 14].

Mineralization - immobilization calculated by the formula:

$\mathrm{K}_{\mathrm{m}-\mathrm{i}}=\mathrm{C}_{\mathrm{KAA}} / \mathrm{C}_{\mathrm{MPA}}$, where $\mathrm{C}_{\mathrm{KAA}}, \mathrm{C}_{\mathrm{MPA}}$, the number of microorganisms that grew on ammonia agar and meat peptonic agar.
Oligotrophity of soil using the formula:

$\mathrm{K}_{\mathrm{ol}}=\mathrm{C}_{\mathrm{PA}} /\left(\mathrm{C}_{\mathrm{KAA}}+\mathrm{C}_{\mathrm{MPA}}\right)$, where $\mathrm{C}_{\mathrm{PA}}$, the number of microorganisms grown on pure agar.

Pedotrophity of soil:

$\mathrm{K}_{\text {ped }}=\mathrm{C}_{\mathrm{S} . \mathrm{A}} / \mathrm{C}_{\mathrm{MPA}}$, where $\mathrm{C}_{\mathrm{S} . \mathrm{A}}$, the number of microorganisms grown on soil agar.

Toxicity of soil samples was determined by the Berestetsky method [15]. The dominant bacteria colonies were isolated by morphological characteristics: colour of colonies, size $(10 \mathrm{~mm}$ or more-large, from 1-10 $\mathrm{mm}$ - average less than $1 \mathrm{~mm}$-point), the edges of the colony, its texture and isolated in pure culture $[16,17]$ Bacteria belonging to different genera and 
species were determined by Bergey [18]. It is established [19-22] that the stimulating effect of microorganisms on plant appears after seed germination. On this established method for detecting microbial stimulants. Enrichment of microbial metabolites is carried out by soaking the seeds in the culture fluid of the studied strains. Broth diluted with water is used for soaking seed culture. Dilution 1:50 - is used at the initial selection of microbial stimulants. Dilution 1:100 is used for a more detailed study of the active strains; 1:200, 1:500 to determine the optimal concentration at which the maximum stimulating effect detected. Radish seeds were used as a biotest. Weight seedling roots, dried at $60{ }^{\circ} \mathrm{C}$ to constant weight were used as the test characteristics. The SE (stimulating effect) expressed in percentage (\%) and was determined by the formula:

$\mathrm{SE}=\left(\mathrm{M}_{\mathrm{r} 1} / \mathrm{M}_{\mathrm{r} 2}\right) \times 100 \%-100$

$\mathrm{M}_{\mathrm{r} 1}$ : weight of roots while processing of culture fluid;

$\mathrm{M}_{\mathrm{r} 2}$ : control weight of roots.

Statistical analyses were conducted using software Statistica 7.0.

\section{Results and Discussion}

There are preserved virgin ecosystems of particular value in the Carpathian Biosphere Reserve. The beech forest's soil microbiota studies are very important, they are sensible reagents to the impact of external factors, ecosystem indicators and succession processes that occur in them [23-25]. We have established that the number of different ecological-trophic groups of soil microorganisms varies with the height of the habitat above sea level. The number of amonificators with increasing height decreased, minimum content organotrophies 1.22 (colony forming units per $1 \mathrm{gr}$. absolutely dry soil) was characterized soil at altitude of 1,100 meters above sea level (Table 2).

As shown in Table 2, at the altitude of 500 meters content of ammonificators was at six times higher and amounted to 7.07 million CFU/gr.ab.d.s., what indicating a significant enrichment of soil organic matter of plant origin. The similar changes in the bacteria content, in the case of bacteria that used mineral nitrogen were observed. The maximum number of these microorganisms -4.32 million CFU/gr.ab.d.s. was in the soil at the altitude of 500 meters above sea level.

At the highest point of sampling $(1,100 \mathrm{~m}$.) their number was 2.82 times lower. Fluctuations of number micromycetes were not as significant as bacterial flora, but in edaphotops located within 500-800 meters their biodiversity was higher than at other sampling points.

The content of microscopic fungi in the soil of virgin ecosystems was 17-28 thousand CFU/gr.ab.d.s. The number of oligotrophic and pedotrophic microbiota with increasing altitude increased, indicating a decrease in nutrients necessary for life of the soil microbiocoenosis (Table 2). In order to assess

Table 2 Number of different ecological-trophic groups of soil microorganisms in the virgin beech forests.

\begin{tabular}{llllllll}
\hline No. & $\begin{array}{l}\text { Altitude } \\
\text { above sea } \\
\text { level, } \mathrm{m}\end{array}$ & \multicolumn{2}{l}{$\begin{array}{l}\text { (CFU-colony forming units/ per 1 gram of absolutely dry soil) } \\
\times 10^{3}\end{array}$} & $\begin{array}{l}\text { Micromycetes, } \\
\times 10^{6}\end{array}$ & $\begin{array}{l}\text { Oligotrophes } \\
\times 10^{6}\end{array}$ & $\begin{array}{l}\text { Pedotrophes } \\
\times 10^{6}\end{array}$ & $\begin{array}{l}\text { Bacteria which are using } \\
\text { mineral forms of nitrogen } \\
\times 10^{6}\end{array}$ \\
\hline 1 & 500 & 17 & 7.07 & 2.33 & 1.68 & 4.32 & 80.23 \\
2 & 600 & 20 & 4.30 & 2.61 & 1.88 & 3.64 & 68.44 \\
3 & 700 & 20 & 3.46 & 2.87 & 2.00 & 3.22 & 60.29 \\
4 & 800 & 21 & 2.93 & 3.24 & 2.26 & 3.14 & 58.56 \\
5 & 900 & 25 & 1.66 & 3.70 & 2.96 & 2.18 & 54.67 \\
6 & 1,000 & 26 & 1.30 & 3.80 & 3.12 & 1.96 & 50.13 \\
7 & 1,100 & 28 & 1.22 & 3.94 & 3.65 & 1.83 & 41.34 \\
$\mathrm{SSD}_{05}-$ & 0.32 & 0.14 & 0.41 & 0.18 & 0.21 & 1.28 \\
\hline
\end{tabular}

$\mathrm{SSD}_{05}$ - smallest significant difference. 
Table 3 Direction of microbiological processes on soil in primeval beech forest.

\begin{tabular}{lllll}
\hline No. & Altitude above sea level, $m$ & Coefficient of oligotrophity & Coefficient of pedotrophity & $\begin{array}{l}\text { Coefficient of } \\
\text { mineralization-immobilization }\end{array}$ \\
\hline 1 & 500 & 0.20 & 0.23 & 0.60 \\
2 & 600 & 0.31 & 0.44 & 0.84 \\
3 & 700 & 0.37 & 0.57 & 0.93 \\
4 & 800 & 0.50 & 0.77 & 1.07 \\
5 & 900 & 0.94 & 1.80 & 1.31 \\
6 & 1,000 & 1.18 & 2.40 & 1.50 \\
7 & 1,100 & 1.29 & 3.00 & 1.50 \\
\hline
\end{tabular}

the direction of microbiological processes in the soil of beech forests the calculation of coefficients of oligotrophity, pedotrophity and mineralization-immobilization were carried out (Table 3).

As can be seen from Table 3, the coefficients of oligotrophity and pedotrophity of soil increased with the altitude and their maximum value were at the height of 1,100 meters respectively 1.29 and 3.00 . Increasing of the pedotrophity indicates an intensity of decomposition of a soil organic matter, including humus substances. The increasing of the oligotrophity of the soil indicates the reduction of nutrients in the soil. Minimum of these coefficients were at the altitude of 500 meters above sea level: the oligotrophity coefficient -0.20 ; coefficient of the pedotrophity -0.23 that of 6.4 times and 13 times less than the maximum values of these parameters in the studied ecosystem. Intensity of mineralization processes in the soil also increased in proportion to height of the investigation edaphotopes and maximum values reached at $1,100 \mathrm{~m}$, the rate of mineralization-immobilization was 1.50 which is 2.5 times higher than in edaphotopes at altitude of $500 \mathrm{~m}$. Succession, dynamic changes of microbial communities of soil related primarily from the impact of biocoenosis abiotic factors such as temperature and humidity.

Rebuilding the functional structure of soil microbial coenosis due to the influence of exogenous factors, as evidenced not only by changing the number of specific ecological-trophic groups of soil microorganisms [26], but also from direction of microbiological processes in soil of virgin ecosystems.

Toxic substances produced by microorganisms enter the plant directly from the soil, and they are concentrated mainly in the overground organs, and almost not observed in the roots of plants. Phytotoxines of soil microorganisms cause significant changes in the chemical composition of plant metabolism to break them (impact on nitrogen and carbohydrate metabolism), inhibit seeds germination, growth of sprouts, plant growth and reduce harvest $[27,28]$. Toxic forms of microorganisms found in all types of soil.

The genera Bacillus and Pseudomonas are more often among the bacteria; among micromycetes-Penicillium, Fusarium; among streptomycetes-Streptomyces aurantiacus, $S$. viridans, S. griseus [29, 30].

Phytotoxines that formed by soil microorganisms belong to different groups of chemical compounds. There are nitrogen-containing and oxygen-containing heterocyclic compounds and aromatic substances acyclic structure, derivatives of phenols, quinones, and terpenoids among them [31]. More important toxic activity of strains and their inhibitory ability, than in the soil they accumulate in large quantities [32, 33]. Soil in virgin forest ecosystems, characterized by relatively low levels of phytotoxic activity: 14\%-21\% (Fig. 2). In contrast, anthropogenically transformed ecosystems characterized by very high levels of phytotoxic activity on average three times higher than background levels. 
The maximum level of phytotoxical activity (21\%) was characterized by samples of soil taken at height of 1,100 meters above sea level. This is due to the high content of oligotrophes (3.94 mln. CFU/1g.a.d.s.), and pedotrophes (3.65 mln. CFU/1g.a.d.s.), including the species producing toxic exometabolites. In general, the virgin forest ecosystems are characterized by relatively low levels of phytotoxical activity of soil in comparison with the anthropogenic ecosystems.

Activity of soil microorganisms determines soil fertility, their environmental and phytosanitary status. In addition, soil microorganisms are indicators of contaminants in ecosystems, as reflected on the level of soil biological activity, including enzymatic activity and the intensity of emission of carbon dioxide from the soil surface. A high level of biological activity of the soil positively affects not only its structure, but also on the growth of plants [34]. The results of the biological activity of the soil by the intensity of emission carbon dioxide are presented on Fig. 3.

The high level of biological activity in the soil is characterized by virgin ecosystems. The intensity of emission of carbon ranged from 89-74 $\mathrm{mg}$ $\mathrm{CO}_{2} / \mathrm{kg}$.soil/day that indicates the favorable environmental conditions for the functioning of soil microorganisms. The biological activity of soil decreased with altitude increasing, due to the slowing of microbiological processes [35] and the reduction of the total number of soil microorganisms.

Microorganisms constitute nearly $1 \%$ of the soil mass and they have a major impact on soil properties and processes. Near $80 \%$ of the soil metabolism is due

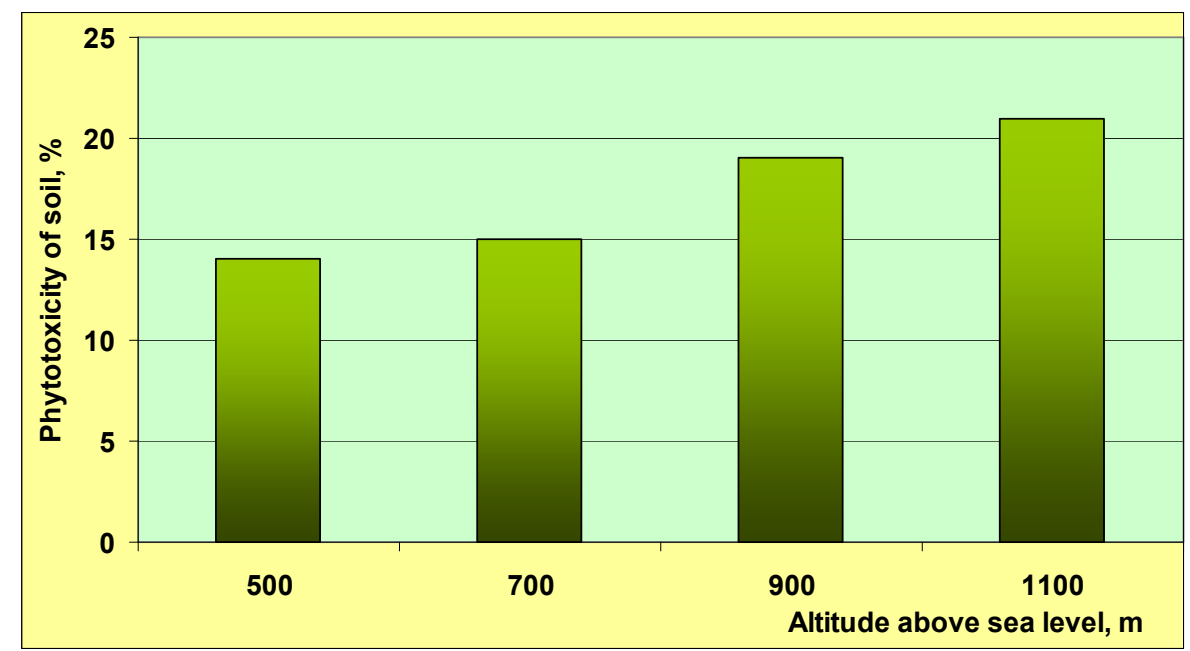

Fig. 2 Phytotoxical activity of soil in virgin beech forests of Shyrokoluzhansky massif of the Carpathian Biosphere Reserve.

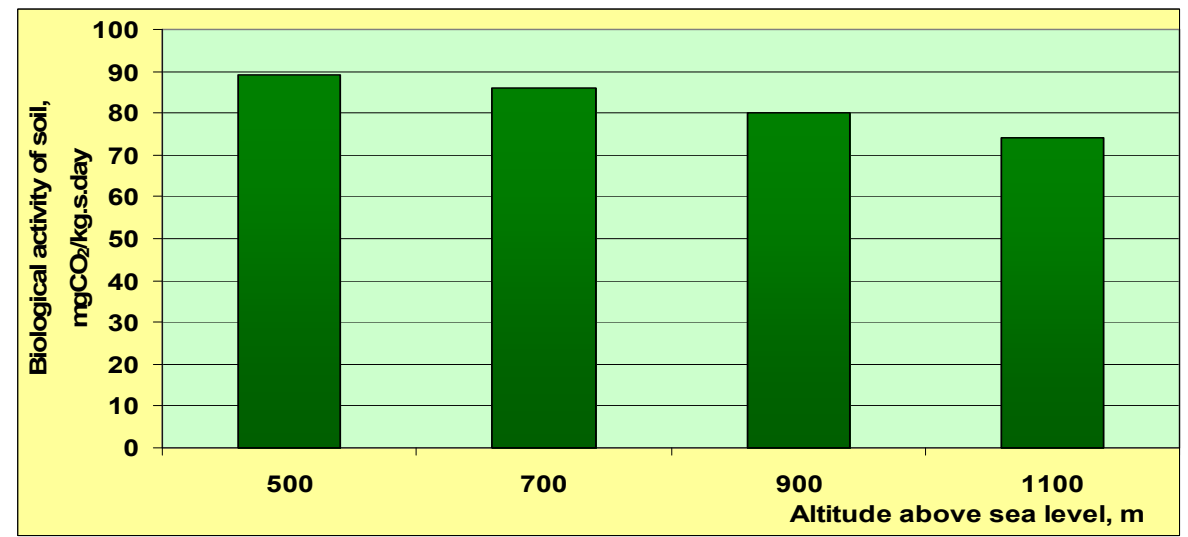

Fig. 3 Biological activity of soil in virgin beech forests of Shyrokoluzhansky massif of the Carpathian Biosphere Reserve. 
Table 4 Stimulating properties of dominant bacteria isolated from soil of Shyrokoluzhansky massif of Carpathian Biosphere Reserve.

\begin{tabular}{|c|c|c|c|c|c|c|c|}
\hline \multirow{2}{*}{ No. } & \multirow{2}{*}{$\begin{array}{l}\text { Altitude above } \\
\text { sea level, } \mathrm{m}\end{array}$} & \multicolumn{2}{|c|}{ Amount of strains } & \multicolumn{4}{|c|}{ Distribution of isolates by stimulating effect } \\
\hline & & Total number & Stimulators & Neutral & $25 \%-50 \%$ & $50 \%-75 \%$ & $75 \%-100 \%$ \\
\hline 1 & 500 & 114 & 33 & 81 & 15 & 18 & - \\
\hline 2 & 600 & 130 & 31 & 99 & 10 & 21 & - \\
\hline 3 & 700 & 135 & 40 & 95 & 22 & 18 & 3 \\
\hline 4 & 800 & 117 & 24 & 93 & 18 & 6 & 1 \\
\hline 5 & 900 & 87 & 16 & 71 & 16 & - & - \\
\hline 6 & 1,000 & 54 & 8 & 46 & 8 & - & - \\
\hline 7 & 1,100 & 49 & 4 & 45 & 4 & - & - \\
\hline
\end{tabular}

to the microbiota. The role of soil microorganisms in the biocoenosis relation to the plants can be both positive and negative. Some of soil bacteria are able to produce a variety of biotic substances with biocatalytic activity [36].

These bacteria activate biological processes in plants and, therefore, are called bacteria activators (stimulators). These bacteria increase germination, accelerate the growth of seedlings, roots, and sometimes even change the nature of the biochemical processes. Our task was to determine the stimulating properties of isolated dominating soil bacteria (Table 4).

During the study period were isolated 4 strains with high growth stimulating properties. These strains by morpho-cultural, physiological and biochemical properties belong to the species Pseudomonas fluorescens, Pseudomonas putida.

Various strains of Pseudomonas produced auxin-and gibberellin-like substances [37, 38].

The most active strains stimulated the growth of cotyledons (12\%-90\%), hypocotyl (2\%-42\%) and roots $(12 \%-38 \%)$ Isolation the bacterial strains with growth-stimulating properties from the soil of primeval beech forests has a great practical importance, in the future they can be used to produce biopreparates for agricultural plants.

\section{Conclusion}

Consequently, the number of representatives of major ecological-trophic groups of the soil microorganisms varies depending on the altitude of forest's biotopes disposition above sea level.

The number of ammonificators and bacteria that use mineral nitrogen decreased with the altitude increasing, the number of oligotrophes and pedotrophes gradually was increasing. The level of the biological activity in the virgin forest's ecosystems was high. The intensity of emission of carbon ranged from 89-74 mg $\mathrm{CO}_{2} / \mathrm{kg}$.soil/day, it indicates about favorable environmental conditions for the soil microorganisms. Coefficients of oligotrophity and pedotrophity of the soil increased with the altitude and their maximum value were at the height of 1,100 meters respectively 1.29 and 3.00. Increasing of the pedotrophity indicates the intensity of decomposition of the soil organic matter, including humus substances.

Phytotoxity of the soil is informative parameter that should be used in the implementation of the soil monitoring research to evaluate the anthropogenic impacts on ecosystems. The phytotoxic activity of the soil was characterized by relatively low level in the primeval beech forests. The maximum level of phytotoxical activity (21\%) was in the soil taken at the height of 1,100 meters above sea level. This is due to the high content of oligotrophes and pedotrophes, including the species producing toxic exometabolites.

Investigation of the biocoenotic activity of the native soil microorganisms is very important aspect. One hundred and fifty-six bacterial strains stimulators were isolated from the soil of the virgin forests of the Shyrokoluzhansky massif of the Carpathian Biosphere Reserve. The four of them have high growth stimulating properties. 


\section{Acknowledgements}

We are grateful to $\mathrm{T}$. Tsykun for her help on the collecting of soil samples in the virgin forests of the Shyrokoluzhansky massif of the Carpathian Biosphere Reserve.

\section{References}

[1] Stoyko, M., and Kopach, V. 2012. Centenary of Establishment of the Primeval Forest Reserves in the Ukrainian Carpathians. Lviv: Prostir M.

[2] Hamor, F., Dovhanych, Y. et al. 2008. Virgin Forests of Transcarpathia. Inventory and Management. Rakhiv: Royal Dutch Society for Nature Conservation.

[3] Debeljak, M. 2006. "Coarse Woody Debris in Virgin and Managed Forest.” Ecological Indicators 6: 733-42.

[4] Bengtsson, J., Nilsson S., Franc A., and Menozzi, P. 2000. "Biodiversity, Disturbances, Ecosystem Function and Management of European Forests." For Ecol. Manag. 132: $39-50$.

[5] Commarmot, B., Bachofen, H., Bundziak, Y., Burgi, A., Ramp, B., Shparyk, Y., Sukhariuk, D., Viter, R., and Zingg, A. 2005. "Structures of Virgin and Managed Beech Forests in Uholka (Ukraine) and Sihlwald (Switzerland): A Comparative Study.” Snow Landsc Res. 79: 56-45.

[6] Commarmot, B., Brändli, U., Hamor, F., and Lavny, V. 2013. Inventory of the Largest Primeval Beech Forest in Europe. A Swiss-Ukrainian Scientific Adventure. Birmensdorf: Swiss Federal Research Institute WSL.

[7] Stephanie, A. E., John, A. B., and Thomas, M. S. 2007. "Isolation and Characterization of Soil Bacteria that Define Terriglobis gen. nov. in the Phyllum Acidobacteria." Appl. and Env. Microbiology 73 (8): 2708-17.

[8] Sylvia, D., Fuhrmann, J., Hartel, P., and Zuberer, D. 2005. Principles and Applications of Soil Microbiology, Second Edition. Person Education Inc. WWF.

[9] Brandli, Ub, and Dowhanytsch, J. 2003. Urwalder im Zentrum Europas. Ein Naturfuhrer durch das Karpaten-Biospharenreservat in der Ukraine. Birmensdorf: Eidgenossische Forschungsanstalt WSL.

[10] Hamor, F. 2008. Virgin Forests of Transcarpathia. Inventory and Management. Rakhiv: CBR.

[11] Nikitina, Z. 1991. Microbiological Monitoring of Terrestrial Ecosystems. Novosibirsk: Nauka.

[12] Kazeev, K. S, Kolesnikov, S. I., and Valkov, V. F. 2004. Biological Diagnostic and Indication of Soil: Methodology and Research Methods. Rostov-on-Don: Nauka.

[13] Tepper, E. Z., Shilnikova, V. K., and Pereversev, G. I.
2005. Practicum on Microbiology. Moscow: Bustard.

[14] Shtatnov, V. 1952. "Methodology for Determining the Biological Activity of Soil." Reports of the Academy of Agricultural Sciences 128: 27-33.

[15] Andreyuk, K. 2001. Function of Microbial Communities in Soils under Anthropogenic Pressure. Kyiv: Talisman.

[16] Volkogon, V. 2010. Experimental Soil Microbiology. Kyiv: Agricultural Science.

[17] Berestetskiy, O. A. 1978. Phytotoxic Properties of Soil Microorganisms. Leningrad: Publisher Academy of Sciences.

[18] Seliber, G. L. 1962. Big Practicum of Microbiology. Moscow: Higher School.

[19] Gray, T. R., and Williams, S. T. 1987. Soil Microorganisms. London: Print.

[20] Holt, J., Krieg, N., and Sneath, P. 1997. Determinant of Bacteria Bergey. New York: Wiley.

[21] Ravira, A. D. 1979. "Biology of the Soil-Root Interface." The Soil-Root Interface. Academic Press, Vol. 43, pp. 145-460.

[22] Eviner, V. T., and Chapin, F. S. 1997. "Plant-Microbial Interactions." Nature 385 (6611): 26-7.

[23] Harwood, C. S., and Greenberg, E. P. 1999. "Mega Roles of Microorganisms.” Science 286 (5442): 1096.

[24] Firn, R. D., and Jones, C. G. 2000. "The Evolution of Secondary Metabolism.” Mol. Microbiol 5: 989-94.

[25] Patyka, V., and Symochko, L. 2013. "Soil Microbiological Monitoring of Natural and Transformed Ecosystems in Transcarpathian Region of Ukraine." Journal of Microbiology 75: 21-31.

[26] Symochko, L., and Dombai, Y., 2007. "Soil Microorganisms as Test Objects in Monitoring Researches of Terrestrial Ecosystems." In Articles of International Scientific Conference Natural Processes of Forming Biodiversity of Aquatic and Terrestrial Ecosystems, 130-5.

[27] Symochko, L. 2013. "Monitoring of Soil Microbial Coenosis in Primeval Beech Forests". In International Conference Primeval Beech Forests. Reference Systems for the Management and Conservation of Biodiversity, Forest Resources and Ecosystem Services, 20.

[28] Tate, R. L. 1997. "Soil Microbial Diversity Research: Whither to Now?" Soil Sci. 162: 605-6.

[29] Cerna, B., Elhottova, D., and Santruckova H. 2003. "Functional Groups of Soil Microbial Community." In International Symposium on Structure and Function of Soil Microbiota, 3-7.

[30] Pedrol, N., Gonzales, L., and Reigosa, M. 2006. "Allelopathy and Biotic Stress." Allelopathy: A Physiological Process with Ecological Implications. Netherlands, 171-209.

[31] Badreiner, M. R., and Talak, V. B. 1998. "Structure and 
Organization of Soil Microorganisms in Different Ecological Systems." Biofutur 180: 19-22.

[32] Alford, É., Perry, L., Qinc, B., Vivanco, J., and Paschke, M. 2007. "A Putative Allelopathic Agent of Russian Knapweed Occurs in Invaded Soils." Soil Biol Biochem 39: $1812-5$.

[33] McCalla, T., and Haskins, F. 1964. "Phytotoxic Substncec from Soil Microorganisms and Crop Residues." Bacteriol Rev. 28 (4): 517.

[34] Matamala, R., and Schlesinger, W. 2000. "Effects of Elevated Atmospheric $\mathrm{CO}_{2}$ on Fine Root Production and Activity in an Intact Temperate Forest Ecosystem." Global Change Biol. 6: 967-79.

[35] Kennedy, A. C., and Gewin, V. L. 1997. "Soil Microbial
Diversity: Present and Future Considerations." Soil Sci. 9: 607-16.

[36] Hackl, E., Zechmeister-Boltenstern, S., Bodrossy, L., and Sessitsch, A. 2004. "Comparison of Diversities and Composition of Bacterial Populations Inhabiting Natural Forest Soils." Appl. Enviro. Microbiol. 70 (9): 5057-65.

[37] Sobieszczański, J., Stempniewicz, R., and Krzyśko T. 1989. "Pseudomonas SP. AG Producer of Plant Growth Regulators." Developments in Soil Science 18: 201-5.

[38] Smolander, A., and Kitunen V. 2002. "Soil Microbial Activities and Characteristics of Dissolved Organic C and $\mathrm{N}$ in Relation to Tree Species." Soil Biol. Biochem. 3: 651-60. 